\title{
EDITORIAL
}

\author{
PENNY BUNDY AND JOHN O'TOOLE \\ Griffith University, Brisbane, Australia
}

\section{Editorial: Innovation, continuity and conversation}

Welcome, readers, to a journal that is both new and not-new, familiar and unfamiliar. This is the first number of the first volume of Applied Theatre Research, published by Intellect Books. It shares much of its editorial policy, its acronym and most of its title with a journal you may already know and use: The Applied Theatre Researcher, formerly (from 2000 to 2012) published by Griffith University in Australia, and since 2003 also incorporating the IDEA Journal. As the editors of both, we are delighted to be setting out with Intellect, with a fresh and handsome look, a much greater visibility and simplified ease of access for both readers and authors. We are also very pleased to be retaining our links with Griffith University, and with IDEA (The International Drama/Theatre and Education Association): from time to time, we will publish special editions devoted to IDEA Congress papers and IDEA projects, and we intend to remain a significant voice in the international drama and theatre education conversation. Our policy - as well, we hope, as our appeal to our readership - has been updated, but not much changed; as our website (http:// www.intellectbooks.co.uk/journals/view-Journal,id=218) indicates, Applied Theatre Research is:

the worldwide journal for theatre and drama in non-traditional contexts. It focuses on drama, theatre and performance with specific audiences or 
participants in a range of social contexts and locations ... Educational uses of theatre are an important part of the journal's brief.

We have retained and expanded the distinguished and truly global team of peer reviewers on our Advisory Board. From this edition onwards, we are now publishing regular reviews of significant applied theatre publications, and we welcome Professor Michael Balfour as Reviews Editor. The Editorial Board now comprises Professor Balfour, Associate Professor Peter O'Connor as our General Adviser and ourselves.

Coincident with these adjustments to and rethinking of our own profile, the 7th International Drama in Education Research Institute (IDIERI) conference was held in July, in Limerick, Ireland, with one of us (Penny) co-convening the 'research hub' - or study group - on publications. One question considered by this group was what readers want from refereed journal articles, and the study group managed to come up with a considered statement at the end. This seems to us to be such good sense that we endorse its general principles, and we are reprinting it here, with a little editorial comment. We invite and encourage our readers who are thinking of submitting an article to us to bear it in mind - along, of course, with our other more particular and specific requirements, as indicated on our website call for papers.

\section{WHAT WE WANT TO READ}

People want to engage with the story of the research. We want a short, relevant, manageable read, with new, up to date, emerging ideas. As readers, we seek a paper that challenges us; that invites dialogue; that has a useful and credible reference list; that gives us something to take away. We want a sense of the practitioner and of the theoretical framework.

Readers want an aesthetically pleasing paper, a writer who appears genuine, metaphor, subtitles and signposts. We don't want utilitarian, formulaic writing. We want work that offers a sense of the context; that offers a sense of the writer and contains the writer's passion.

We want an abstract that lets us decide if we want to continue to read, one that can be understood by someone outside the field. And we want those who have contributed to the work to be credited in the work.

To these points we would add that if it is an article based on a research project, along with the theoretical framework, we also want a brief but convincing explanation of the methodology and procedures including the practice or fieldwork (but not a blow-by-blow account). We underline the importance of hearing the researcher or practitioner's voice, not an abstracted and 'objectivized' account by anonymous researchers: the words ' $\mathrm{I}$ ' and 'we' are fine (though not to excess!). We also point out that most of the journal's readers or at least the central readership - are our peers, those already informed about applied theatre and with a background in the relevant literature; most others are in connected fields or, if lay readers, have a basic interest and understanding. This means that basic concepts and knowledge, and understandings that can be said to be common currency in our field - its public domain - need not be explained laboriously from scratch, or referenced with a lengthy list of readings the writer happens to have come across (which, we 
emphasise, can unwittingly reveal to a truly scholarly reader a writer's ignorance as much as their learning). It also means that references can and should be kept to a minimum - just relevant readings and quotations that are germane to the article and specific to the concepts and points being expounded in it. We welcome and encourage new writers, and recent and current scholars, to submit articles to us, but stress that a learned article is very different from a dissertation or thesis: you do not have to prove your erudition - it is assumed, as it is assumed that you have something new and worthwhile to say, and will say it in an interesting and engaging way, just as those IDIERI participants demanded.

This issue of Applied Theatre Research showcases the diversity of applied theatre, with vivid descriptions of participants and practices in Australia, Brazil, Greece, Hong Kong, Palestine, Serbia, South Africa, Sweden, Taiwan and the United Kingdom. It also clearly evokes applied theatre's multi-layered complexity - passionate but thoughtful advocacy, conscientiously evaluative approaches, perceptive problematization, and sharp-eyed critique of our field and our assumptions are all demonstrated in these pages. Several common themes provide for a number of lively conversations, which have emerged quite fortuitously (we are as dependent as most other journals on whatever submissions arrive in our e-mail in-boxes).

Perhaps the most noticeable common thread is a significant re-evaluation of some of the tenets of critical pedagogy by which many of us have been influenced - and with which we probably have become far too comfortable. Kennedy Chinyowa takes these tenets and their holders to task explicitly. He pins his scholarly critique down with a vivid and uncomfortable example of the dangers inherent in too simplistic a reading of cultural assumptions in South Africa's contemporary melting pot. The incident to which he refers took place significantly in a teacher education setting, where the cultural trend-setters for the next generation of children and young people are being trained. Using a critical reading of Bourdieu's notion of habitus, Beatriz Cabral gives the limits of critical pedagogy a stretch, reaching simultaneously back to the classic drama teaching of the late Dorothy Heathcote and forward to a model of disruptive pedagogy derived from the analysis of multi-player role-play games.

Other contributors disturb the fixity of any dramatic representation of cultural assumptions - most vividly Jack Shu, who found himself up to his neck in a real cultural and generational conflict (all about clashing readings of an audience of schoolchildren in a TIE program, who had been given 'special' headbands to wear - an enrolment strategy that countless drama teachers and TIE teams have used for years to build belief in young participants). Shu resolutely uses his and his team's discomfiture to generate wise recommendations about culture, situation and place. This discussion resonates excitingly with Sally Mackey's insightful reflections on place and space - places and spaces and their meanings, as manifested and explored by visiting artists, primary school children and parents, and their principal. Her study took place in a school where, after reading her account, we would like to teach - even though (or perhaps partly because) the feared UK school standards authority Ofsted found it wanting.

Morag Morrison, Elin Nilsson and Margaret Lepp join Kennedy Chinyowa's conversation about teacher education, bringing their own diverse backgrounds to bear - two of them from nursing education - in exploring what teachers in pre-service education with no experience of drama get from a drama-rich course of study. Narrative, especially how people 'story' their 
lives, forms an implicit conversational theme, and this is made fully explicit in Sarah Woodland's account of working with women in prison - again with the author boldly facing some not very comfortable home truths.

The final two articles provide an independent and refreshing contrast, not only to the various conversations mentioned above, but to each other. Eva Österlind shrewdly and very usefully scrutinises some of the procedures and instruments available for evaluating and researching applied theatre projects, using three examples spread across the globe; she also helpfully clarifies the distinction between evaluation and research. Using interviewees who were also spread around the world, Ioannis Grammatopoulos and Martina Reynolds hold their own conversation with their informants to reflect upon and re-evaluate some of the basic relationships between actors, audience and their respective 'selves', which make theatre efficacious.

Finally, although it is not the normal policy of this journal to include obituaries, we proudly include the moving tribute to the late Dorothy Heathcote delivered by Pam Bowell at Heathcote's memorial tribute service with an explanation of why we are breaking that rule in this special instance.

We hope you enjoy this edition. We hope it inspires you to think about, and do some, applied theatre ... and then write about it and send it to us (following our guidelines above and on the website, of course). Then we look forward to renewing your company in the continuing conversation that is Applied Theatre Research, the next issue.

Penny Bundy and John O'Toole have asserted their right under the Copyright, Designs and Patents Act, 1988, to be identified as the author of this work in the format that was submitted to Intellect Ltd. 